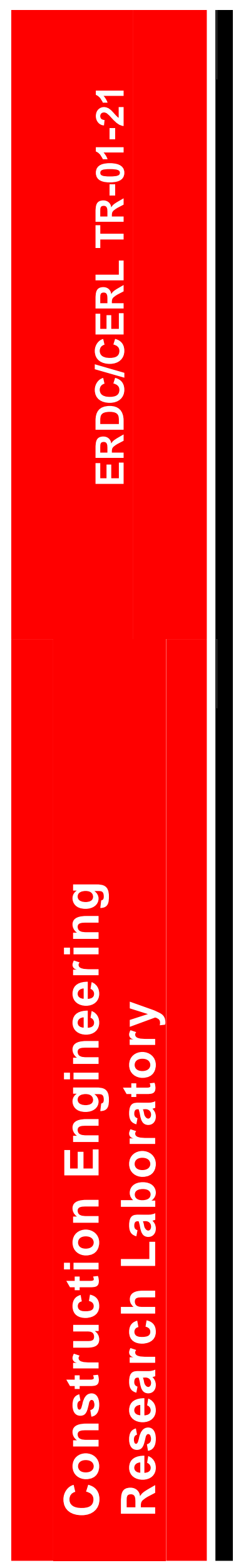

\title{
Site Evaluation for Application of Fuel Cell Technology
}

\section{Naval Education Training Center, Newport, RI}

Michael J. Binder, Franklin H. Holcomb, and William R. Taylor
February 2001 


\section{Foreword}

In fiscal years 93 and 94, Congress provided funds for natural gas utilization equipment, part of which was specifically designated for procurement of natural gas fuel cells for power generation at military installations. The purchase, installation, and ongoing monitoring of 30 fuel cells provided by these appropriations has come to be known as the "DOD Fuel Cell Demonstration Program." Additional funding was provided by: the Office of the Deputy Under Secretary of Defense for Industrial Affairs \& Installations, ODUSD (IA\&I)/HE\&E; the Strategic Environmental Research \& Development Program (SERDP); the Assistant Chief of Staff for Installation Management (ACSIM); the U.S. Army Center for Public Works (CPW); the Naval Facilities Engineering Service Center (NFESC); and Headquarters (HQ), Air Force Civil Engineer Support Agency (AFCESA).

This report documents work done at Naval Education Training Center, Newport, RI. Special thanks is owed to the Naval Education Training Center points of contact (POCs), J ohn Alfano and Bob Parent, for providing investigators with access to needed information for this work. The work was performed by the Energy Branch (CF-E), of the Facilities Division (CF), Construction Engineering Research Laboratory (CERL). The CERL Principal Investigator was Michael J . Binder. Part of this work was performed by Science Applications International Corp. (SAIC), under Contract DACA88-94-D-0020, task orders 0002, 0006, 0007, 0010, and 0012. The technical editor was William J . Wolfe, Information Technology Laboratory. Larry M. Windingland is Chief, CEERD-CF-E, and L. Michael Golish is Chief, CEERD-CF. The associated Technical Director was Gary W. Schanche. The Acting Director of CERL is William D. Goran.

CERL is an element of the U.S. Army Engineer Research and Development Center (ERDC), U.S. Army Corps of Engineers. The Director of ERDC is Dr. J ames R. Houston and the Commander is COL J ames S. Weller.

\section{DISCLAIMER}

The contents of this report are not to be used for advertising, publication, or promotional purposes. Citation of trade names does not constitute an official endorsement or approval of the use of such commercial products. All product names and trademarks cited are the property of their respective owners.

The findings of this report are not to be construed as an official Department of the Army position unless so designated by other authorized documents.

DESTROY THIS REPORT WHEN IT IS NO LONGER NEEDED. DO NOT RETURN IT TO THE ORIGINATOR. 


\section{Contents}

Foreword

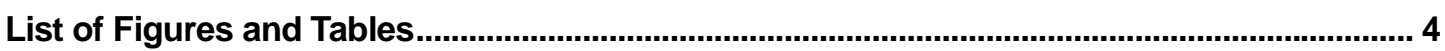

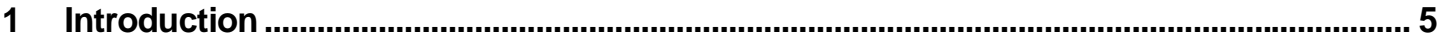

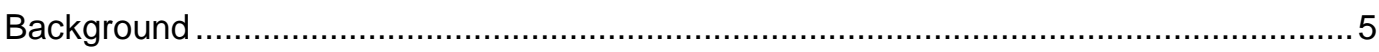

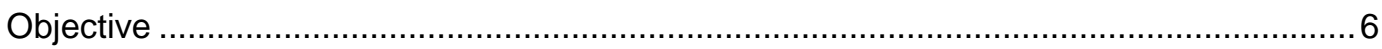

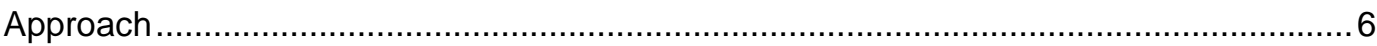

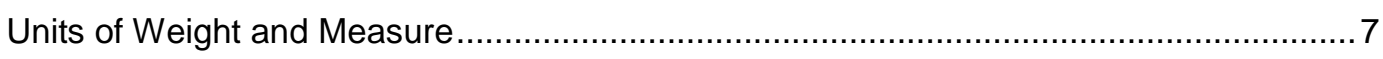

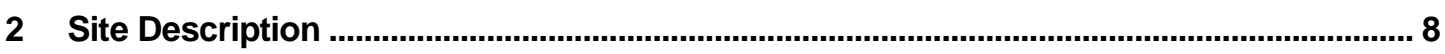

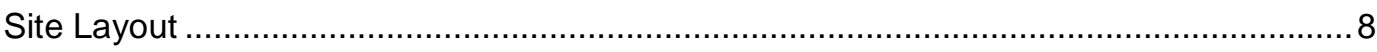

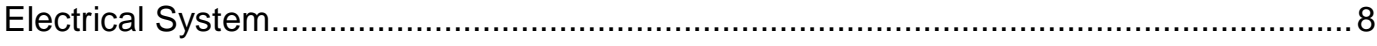

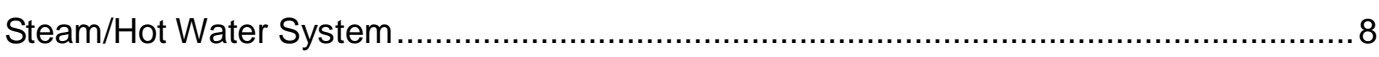

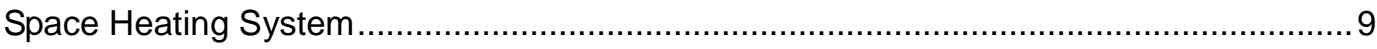

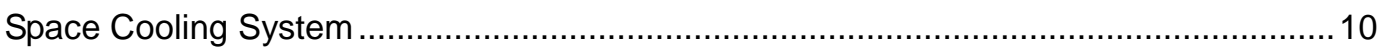

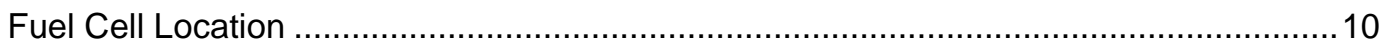

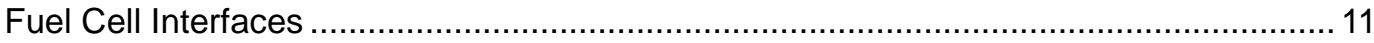

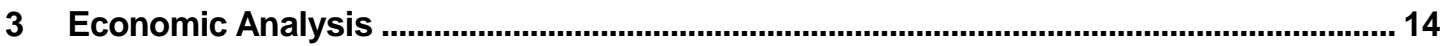

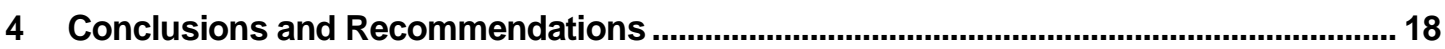

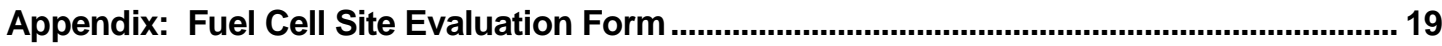

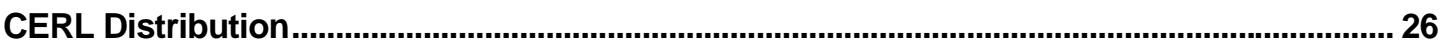

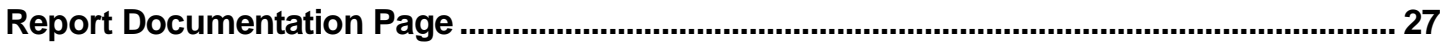




\section{List of Figures and Tables}

\section{Figures}

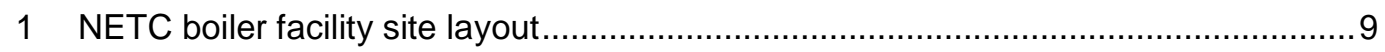

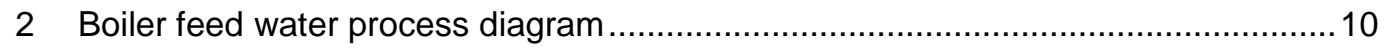

3 Fuel cell location with proposed thermal and electric runs.................................... 11

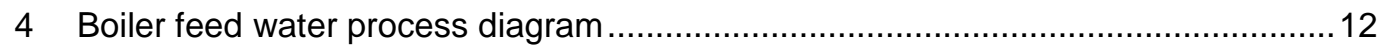

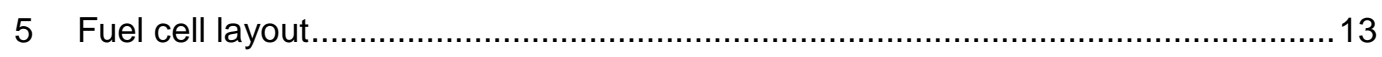

\section{Tables}

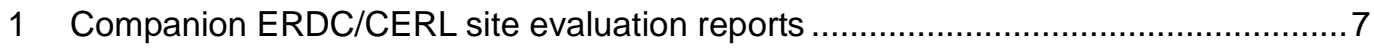

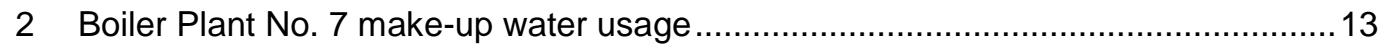

3 Newport Naval Education Training Center electricity consumption ..........................14

4 Newport Electric Corporation rate schedule at NETC .............................................15

5 Economic savings of fuel cell design alternatives ................................................. 16 


\section{Introduction}

\section{Background}

Fuel cells generate electricity through an electrochemical process that combines hydrogen and oxygen to generate direct current (DC) electricity. Fuel cells are an environmentally clean, quiet, and a highly efficient method for generating electricity and heat from natural gas and other fuels. Air emissions from fuel cells are so low that several Air Quality Management Districts in the United States have exempted fuel cells from requiring operating permits. Today's natural gasfueled fuel cell power plants operate at electrical conversion efficiencies of 40 to 50 percent; these efficiencies are predicted to climb to 50 to 60 percent in the near future. In fact, if the heat from the fuel cell process is used in a cogeneration system, efficiencies can exceed 85 percent. By comparison, current conventional coal-based technologies operate at efficiencies of 33 to 35 percent.

Phosphoric Acid Fuel Cells (PAFCs) are in the initial stages of commercialization. While PAFCs are not now economically competitive with other more conventional energy production technologies, current cost projections predict that PAFC systems will become economically competitive within the next few years as market demand increases.

Fuel cell technology has been found suitable for a growing number of applications. The National Aeronautics and Space Administration (NASA) has used fuel cells for many years as the primary power source for space missions and currently uses fuel cells in the Space Shuttle program. Private corporations have recently been working on various approaches for developing fuel cells for stationary applications in the utility, industrial, and commercial markets. Researchers at the U.S. Army Engineer Research and Development Center (ERDC), Construction Engineering Research Laboratory (CERL) have actively participated in the development and application of advanced fuel cell technology since fiscal year 1993 (FY93), and have successfully executed several research and demonstration work units with a total funding of approximately $\$ 55 \mathrm{M}$.

As of November 1997, 30 commercially available fuel cell power plants and their thermal interfaces have been installed at DoD locations, CERL managed 29 of these installations. As a consequence, the Department of Defense (DoD) is the 
owner of the largest fleet of fuel cells worldwide. CERL researchers have developed a methodology for selecting and evaluating application sites, have supervised the design and installation of fuel cells, and have actively monitored the operation and maintenance of fuel cells, and compiled "lessons learned" for feedback to manufacturers. This accumulated expertise and experience has enabled CERL to lead in the advancement of fuel cell technology through major efforts such as the DoD Fuel Cell Demonstration Program, the Climate Change Fuel Cell Program, research and development efforts aimed at fuel cell product improvement and cost reduction, and conferences and symposiums dedicated to the advancement of fuel cell technology and commercialization.

This report presents an overview of the information collected at Naval Education Training Center, Newport, RI along with a conceptual fuel cell installation layout and description of potential benefits the technology can provide at that location. Similar summaries of the site evaluation surveys for the remaining 28 sites where CERL has managed and continues to monitor fuel cell installation and operation are available in the companion volumes to this report (Table 1).

\section{Objective}

The objective of this work was to evaluate Naval Education Training Center as a potential location for a fuel cell application.

\section{Approach}

On 10 and 11 May 1994, Science Applications International Corporation (SAIC) visited the Newport, Rhode Island Naval Education and Training Center (NETC) to investigate it as a potential location for a $200 \mathrm{~kW}$ phosphoric acid fuel cell. This report presents an overview of information collected at NETC (the site) along with a conceptual fuel cell installation layout and description of potential benefits. The Appendix to this report contains a copy of the site evaluation form filled out at the site. 
Table 1. Companion ERDC/CERL site evaluation reports.

\begin{tabular}{|c|c|}
\hline Location & Report No. \\
\hline Pine Bluff Arsenal, AR & TR $00-15$ \\
\hline Naval Oceanographic Office, John C. Stennis Space Center, MS & TR 01-3 \\
\hline Fort Bliss, TX & TR $01-13$ \\
\hline Fort Huachuca, AZ & TR $01-14$ \\
\hline Naval Air Station Fallon, NV & TR $01-15$ \\
\hline Construction Battalion Center (CBC), Port Hueneme, CA & TR $01-16$ \\
\hline Fort Eustis, VA & TR $01-17$ \\
\hline Watervliet Arsenal, Albany, NY & TR $01-18$ \\
\hline $911^{\text {th }}$ Airlift Wing, Pittsburgh, PA & TR 01-19 \\
\hline Westover Air Reserve Base (ARB), MA & TR $01-20$ \\
\hline Naval Education Training Center, Newport, RI & TR $01-21$ \\
\hline U.S. Naval Academy, Annapolis, MD & TR $01-22$ \\
\hline Davis-Monthan AFB, AZ & TR $01-23$ \\
\hline Picatinny Arsenal, NJ & TR $01-24$ \\
\hline U.S. Military Academy, West Point, NY & TR $01-28$ \\
\hline Barksdale Air Force Base (AFB), LA & TR $01-29$ \\
\hline Naval Hospital, Naval Air Station Jacksonville, FL & TR $01-30$ \\
\hline Nellis AFB, NV & TR $01-31$ \\
\hline Naval Hospital, Marine Corps Air Ground Combat Center (MCAGCC), Twentynine Palms, CA & TR 01-32 \\
\hline National Defense Center for Environmental Excellence (NDCEE), Johnstown, PA & TR $01-33$ \\
\hline $934^{\text {th }}$ Airlift Wing, Minneapolis, MN & TR 01-38 \\
\hline Laughlin AFB, TX & TR $01-41$ \\
\hline Fort Richardson, AK & TR $01-42$ \\
\hline Kirtland AFB, NM & TR $01-43$ \\
\hline Subase New London, Groton, CT & TR $01-44$ \\
\hline Edwards AFB, CA & TR 01-Draft \\
\hline Little Rock AFB, AR & TR 01-Draft \\
\hline Naval Hospital, Marine Corps Base Camp Pendleton, CA & TR 01-Draft \\
\hline U.S. Army Soldier Systems Center, Natick, MA & TR 01-Draft \\
\hline
\end{tabular}

\section{Units of Weight and Measure}

U.S. standard units of measure are used throughout this report. A table of conversion factors for Standard International (SI) units is provided below.

$\begin{array}{lll}1 \mathrm{ft} & = & 0.305 \mathrm{~m} \\ 1 \mathrm{mile} & = & 1.61 \mathrm{~km} \\ 1 \mathrm{acre} & = & 0.405 \mathrm{ha} \\ 1 \mathrm{gal} & = & 3.78 \mathrm{~L} \\ { }^{\circ} \mathrm{F} & ={ }^{\circ} \mathrm{C}(\mathrm{X} 1.8)+32\end{array}$




\section{Site Description}

NETC is located in Newport, RI, which is approximately 30 miles south of the city of Providence. NETC consists of a wide range of buildings including office buildings, central plants, docking facilities, etc. Temperatures range from the teens in the winter to the mid $90 \mathrm{~s}^{\circ} \mathrm{F}$ in the summer. A central boiler facility (Boiler Plant \#) was identified as the best location for a $200 \mathrm{~kW}$ fuel cell at NETC. The building is approximately $100 \times 100 \mathrm{ft}(10,000 \mathrm{sq} \mathrm{ft})$ and is over three stories tall. The building contains three boilers rated at approximately $75,000 \mathrm{lb} / \mathrm{hr}$. The peak building electric load is around $60 \mathrm{~kW}$.

\section{Site Layout}

Figure 1 presents the site layout for the boiler facility. A new high pressure gas line was just installed at the building's southeast corner. The new gas line will be used to run the \#3 boiler in Boiler Plant \#, and can be tapped into for supplying the fuel cell input natural gas. The electrical transformer is located on the north side of the building. Up a flight of stairs on the south side of the building is the deaerator system for the boilers. Approximately $30 \mathrm{ft}$ from the building is an old warehouse building that is slated for demolition in the near future. On the west side of the building are fuel storage tanks. Efforts are presently underway to remove a few of the tanks, and ultimately all of them will be removed and replaced by a larger tank away from the boiler facility.

\section{Electrical System}

The boiler facility is supplied by a $2400 / 480$ volt transformer (500 kVA), which is located outside on the south side of the building. Electrical switch gear is located on the inside of the building

\section{Steam/Hot Water System}

The boiler facility has two Riley Stoker Corp. boilers $(75,000 \mathrm{lb} / \mathrm{hr})$ that were built in 1959 and one Nebraska boiler (80,000 lb/hr) built in 1986. The Nebraska boiler is dual fueled and can run off of the new natural gas line just installed. 


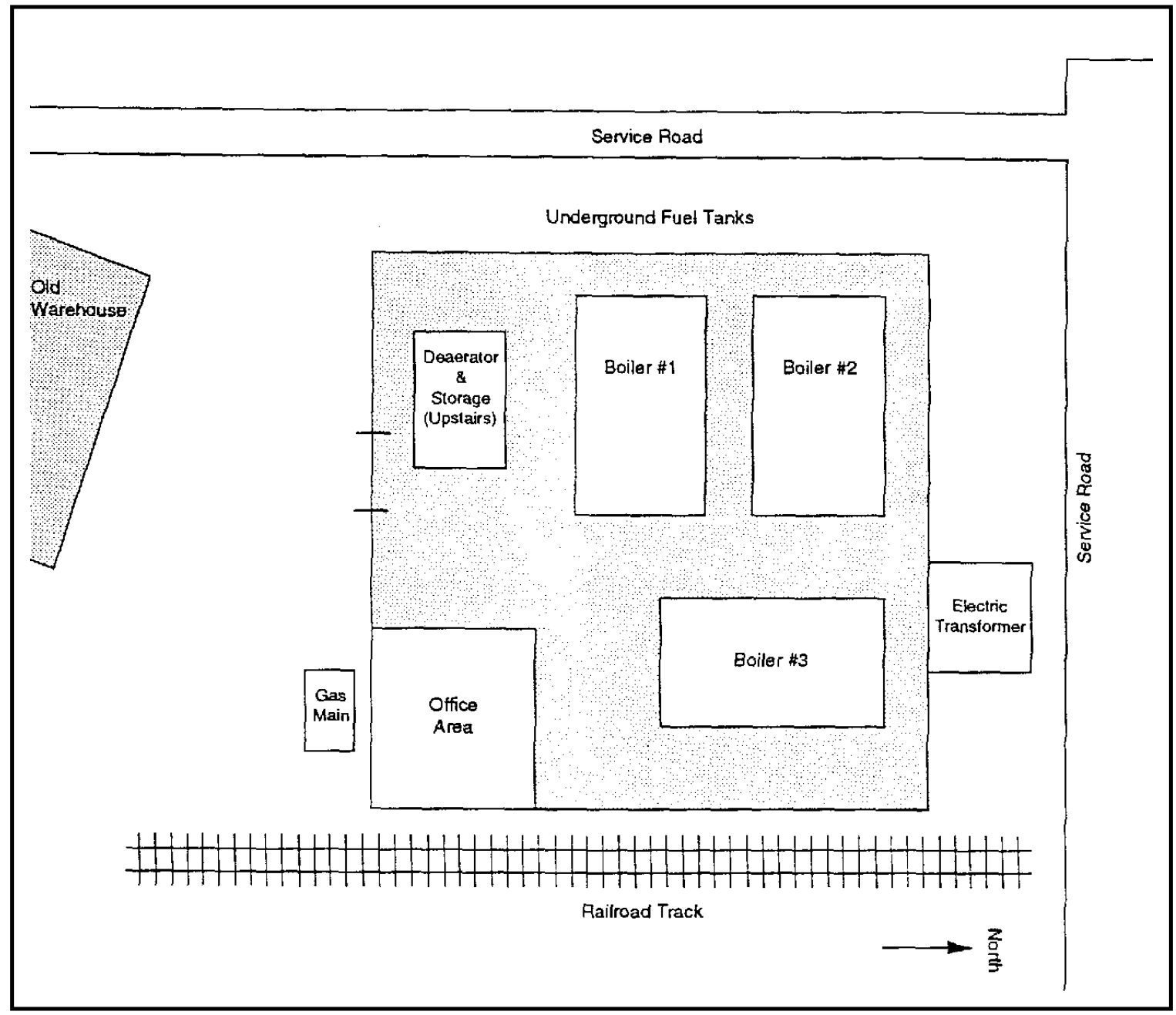

Figure 1. NETC boiler facility site layout.

City water is fed into three 375-gal water softeners and then fed up to a deaerating heater. The deaerator also receives water (and heat) from the condensate return loop (Figure 2). The existing steam loop is over 20 miles in length. Because of leaks in the system, the condensate return is only 17 percent of the steam sent out. Water is fed from the deaerator into a storage tank until it is needed for the boiler.

\section{Space Heating System}

Steam is sent out to various locations at NETC. Hydronic systems are located in individual buildings. 


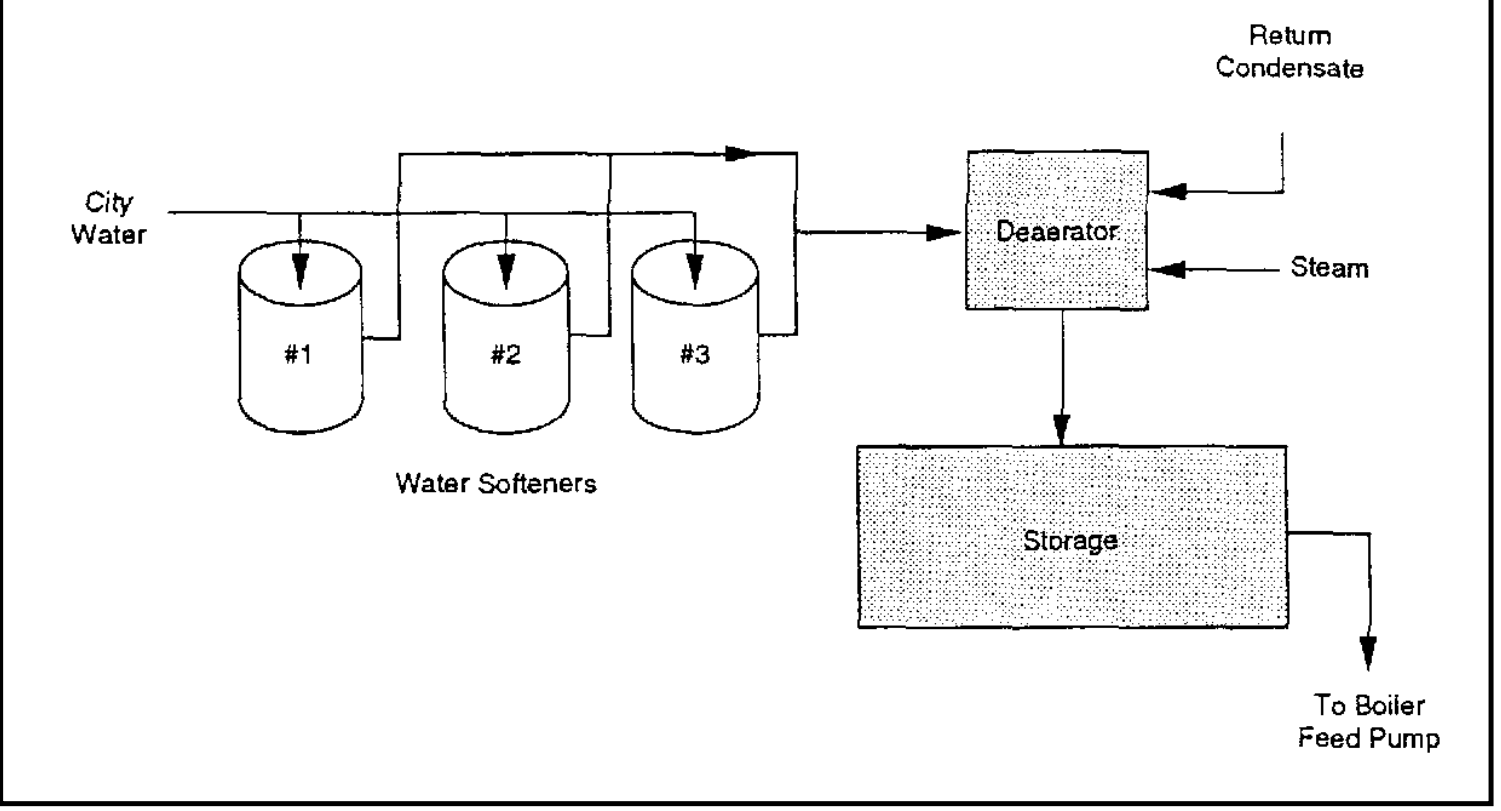

Figure 2. Boiler feed water process diagram.

\section{Space Cooling System}

The steam system does not drive any absorption chillers.

\section{Fuel Cell Location}

An old warehouse is located on the south side of the building. It is slated for demolition, and NETC personnel are working to expedite this process. This is currently the best location for the fuel cell and it is approximately $30 \mathrm{ft}$ from the boiler facility. Because of the underground fuel tanks on the west side of the building, the fuel cell could not be located right up against the building.

Figure 3 presents the location of the proposed fuel cell site along with proposed thermal and electric runs. The thermal run will be approximately $50 \mathrm{ft}$ across to Boiler Plant \#7. Because of underground pipes, it was recommended by Site personnel that the electrical and thermal runs be made across a trellis approximately 15 to $20 \mathrm{ft}$ above the ground. Since the electrical transformer is on the north side of the building, electrical conduit should be run on the outside of the west side of the building and then across the north side. The electrical interface should be made on the 480 volt side of the transformer. 


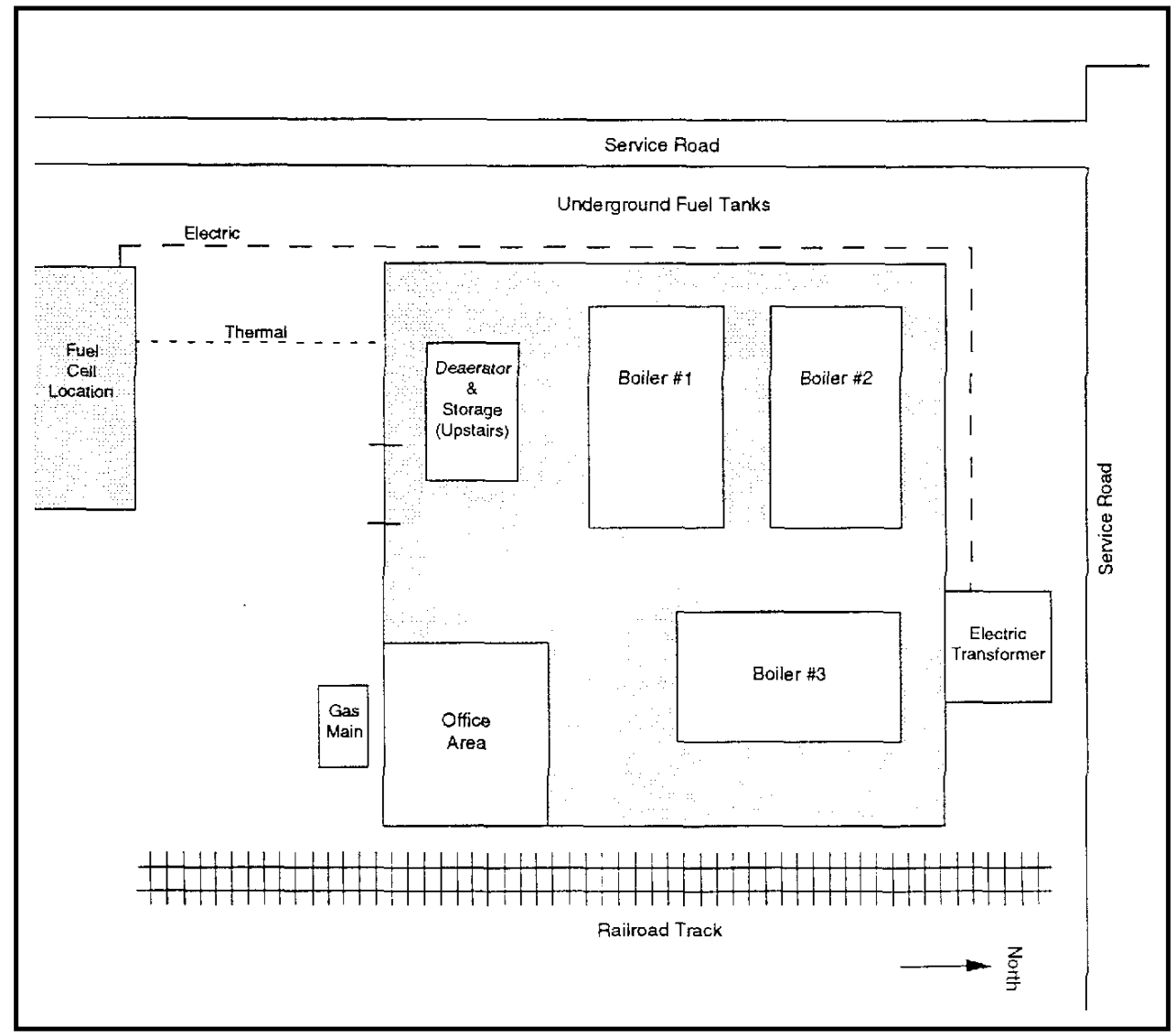

Figure 3. Fuel cell location with proposed thermal and electric runs.

Electric power is supplied to Boiler Plant \#/ through a 2400/480 volt, 500 kVA transformer on the north side of the building. It is recommended that the fuel cell be tied into the 480 volt side of the transformer. The estimated electric load of the building is $60 \mathrm{~kW}$. Approximately two-thirds of the fuel cell output will be fed back to the NETC grid when the boiler facility is in operation.

\section{Fuel Cell Interfaces}

The proposed fuel cell thermal interface is to pre-heat the boiler make-up water (see Figure 4). Table 2 lists the make-up water usage for the last 3 years. The water usage varied significantly from year to year. This is due to the fact that there are two boiler plants at the Site. These two plants are interconnected. Steam can be fed into the delivery system by either plant or both plants and maintenance activities varied between the facilities. This redundancy allows plants to be taken off-line for maintenance for an extended period of time. When the fuel cell is installed, Site personnel should make an effort to keep Boiler Plant \#/ on-line as much as possible to maximize the benefits of the fuel cell thermal output. 


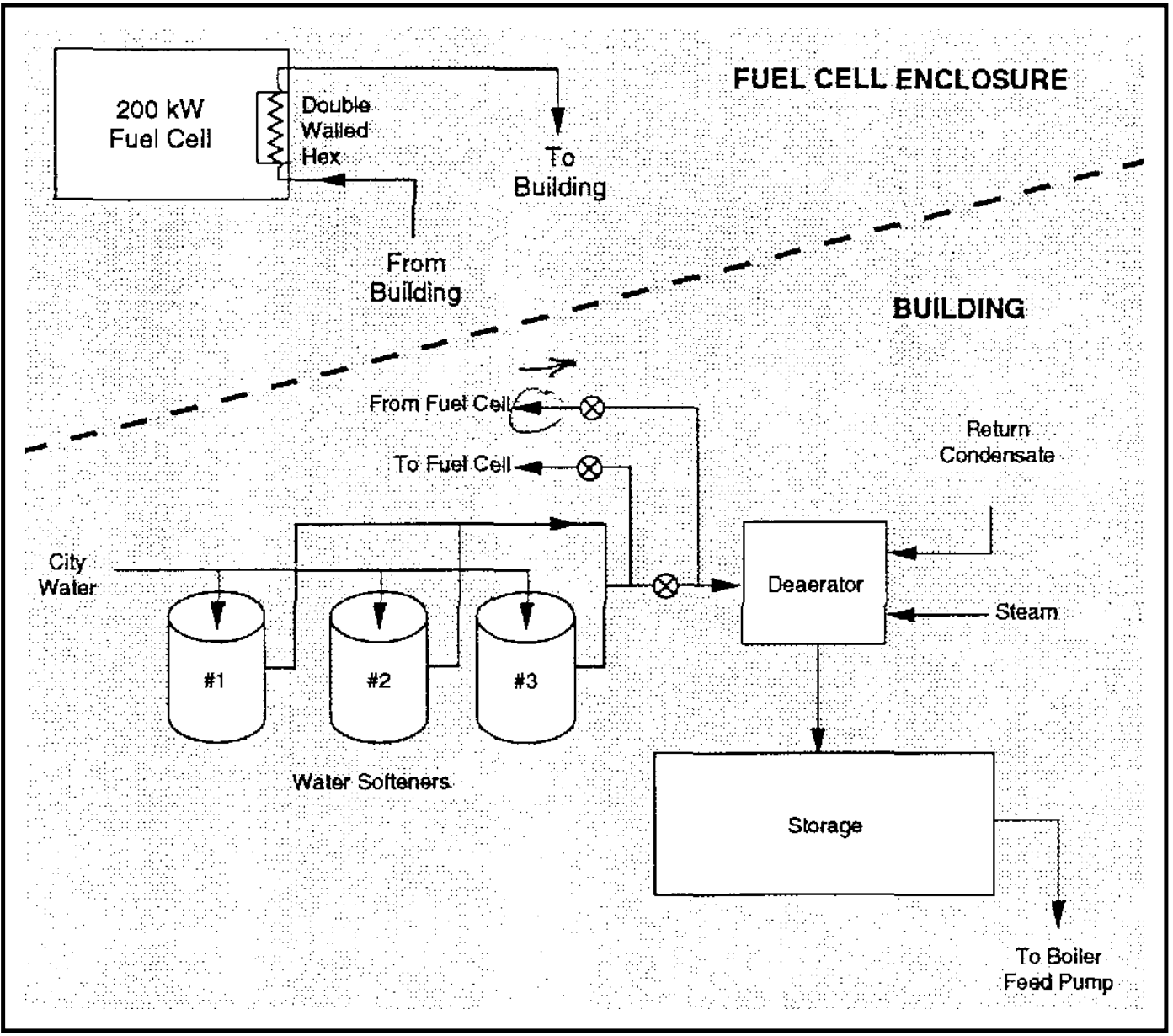

Figure 4. Boiler feed water process diagram.

Hourly make-up water usage data for 25 February 1994 were examined to determine variation in usage and the possible need for thermal storage. The hourly readings showed that the usage profile was fairly flat with a low reading of $6,480 \mathrm{gal} / \mathrm{hr}$ and a high reading of $7,290 \mathrm{gal} / \mathrm{hr}$. Since the typical minimum usage does not fall below the threshold requirement of the fuel cell ( $840 \mathrm{gal} / \mathrm{hr}$ ), thermal storage would not be required.

Using an average hourly make-up water flow rate for each month, the thermal supplied by the fuel cell was calculated. Based on the make-up water consumption for 1991 (Table 2), 60 percent of the fuel cell thermal output could be utilized by the boiler facility. In 1992 and 1993, 59 and 92 percent or the thermal output could be used by the boiler facility, respectively. At these flow rates and an assumed city water temperature of $60^{\circ} \mathrm{F}$, the fuel cell will supply about $160^{\circ} \mathrm{F}$ water. Figure 5 shows a layout of the fuel cell site area. 
Table 2. Boiler Plant No. 7 make-up water usage.

\begin{tabular}{|l|r|r|r|r|r|r|}
\hline \multirow{2}{*}{ Date } & \multicolumn{2}{|c|}{ FY91 } & \multicolumn{2}{c|}{ FY92 } & \multicolumn{2}{c|}{ FY93 } \\
\cline { 2 - 7 } & gal/mo. & F.C. TU* & gal/mo. & F.C. TU & gal/mo. & F.C. TU \\
\hline October & 0 & $0 \%$ & 52,364 & $8 \%$ & $1,318,700$ & $100 \%$ \\
\hline November & 577,980 & $94 \%$ & 0 & $0 \%$ & $5,088,100$ & $100 \%$ \\
\hline December & 607,126 & $99 \%$ & 0 & $0 \%$ & $5,905,500$ & $100 \%$ \\
\hline January & $2,047,630$ & $100 \%$ & 0 & $0 \%$ & $7,393,800$ & $100 \%$ \\
\hline February & $2,397,876$ & $100 \%$ & $5,031,616$ & $100 \%$ & $8,499,700$ & $100 \%$ \\
\hline March & $1,637,610$ & $100 \%$ & $5,247,000$ & $100 \%$ & $8,772,000$ & $100 \%$ \\
\hline April & $1,290,750$ & $100 \%$ & $9,549,378$ & $100 \%$ & $6,944,599$ & $100 \%$ \\
\hline May & 580,450 & $95 \%$ & $5,042,000$ & $100 \%$ & $4,159,300$ & $100 \%$ \\
\hline June & 64,714 & $10 \%$ & $5,042,000$ & $100 \%$ & $3,271,700$ & $100 \%$ \\
\hline July & 43,966 & $7 \%$ & $3,266,700$ & $100 \%$ & $8,367,900$ & $100 \%$ \\
\hline August & 10,868 & $2 \%$ & 964,861 & $59 \%$ & $3,387,900$ & $100 \%$ \\
\hline September & 67,184 & $11 \%$ & 0 & $0 \%$ & & 0 \\
\hline Average & 777,180 & $60 \%$ & $2,849,660$ & $56 \%$ & $5,259,100$ & $92 \%$ \\
\hline
\end{tabular}

${ }^{\star}$ F.C. $T U$ = fuel cell thermal utilization

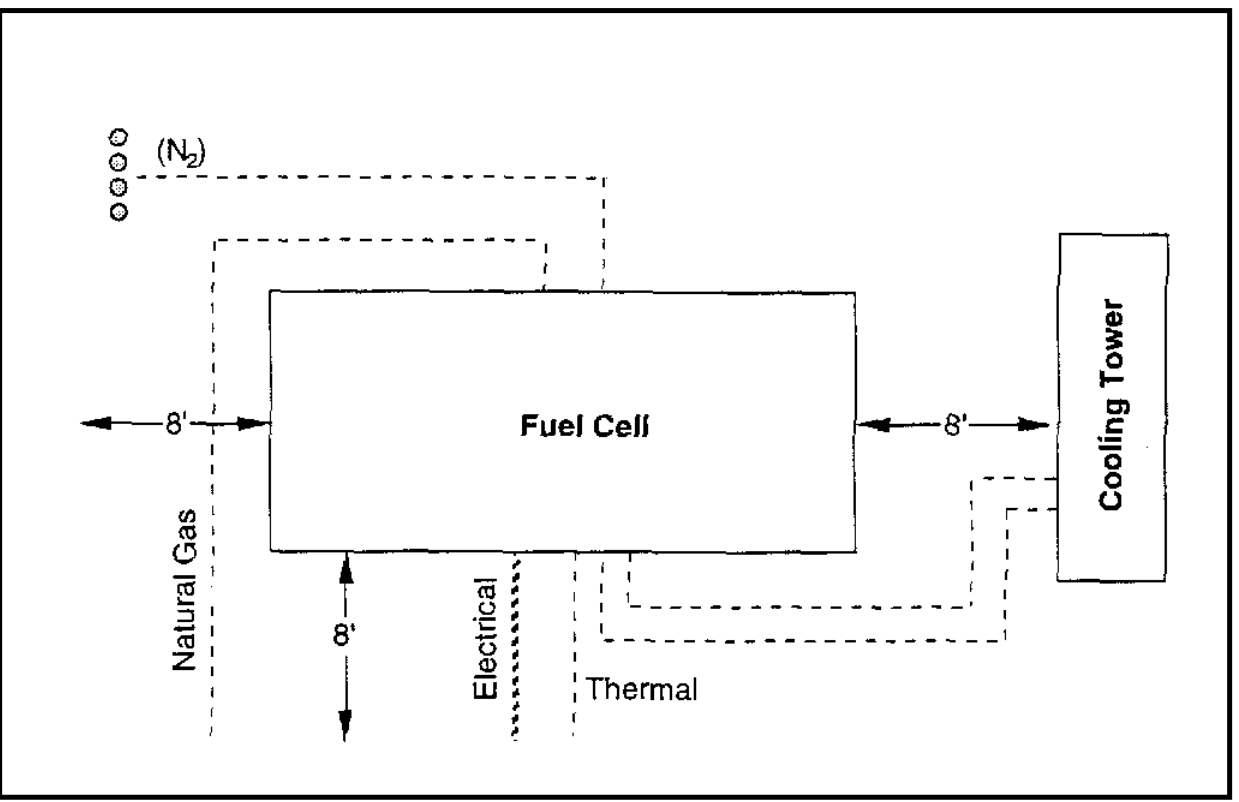

Figure 5. Fuel cell layout. 


\section{Economic Analysis}

NETC is located in Newport Electric Corporation's (a subsidiary of Eastern Utilities) service territory. Table 3 lists electric bills for 1993. The average rate ranged from 9.01 cents/kWh in April to 9.99 cents $/ \mathrm{kWh}$ in August. The average electric rate paid by the Site in 1993 was 9.49 cents/kWh. The site is billed under a special government contract rate schedule, which is a time-of-use rate. The rate schedule does not have separate rates for "summer" and "winter" months. The on-peak period is between 10:00 a.m. and 4:00 p.m. Monday through Friday (April through September) and 8:00 a.m. to 11:00 a.m. and 4:00 p.m. to 9:00 p.m. Monday through Friday (October through March). The off-peak period is all remaining hours including weekends and holidays. Table 4 lists the demand and energy electric rates under the NETC rate schedule.

The Site receives natural gas from the Providence Gas Company. A new high pressure gas line was just installed at Boiler Plant \#/ and no gas bills were provided by the Site. The gas company expects that the firm gas rate for the fuel cell will be $\$ 4.75 / \mathrm{MBtu}$ and that the boiler plant gas rate (60 day interruptible) will be $\$ 4.25 / \mathrm{MBtu}$.

Table 3. Newport Naval Education Training Center electricity consumption.

\begin{tabular}{|l|c|c|c|c|c|c|}
\hline Date & $\begin{array}{c}\text { Peak } \\
\text { KW }\end{array}$ & $\begin{array}{c}\text { On-Peak } \\
\mathbf{k W h}\end{array}$ & $\begin{array}{c}\text { Off-Peak } \\
\mathbf{k W h}\end{array}$ & $\begin{array}{c}\text { Total } \\
\mathbf{k W h}\end{array}$ & $\begin{array}{c}\text { Total } \\
\text { Bill }\end{array}$ & $\mathbf{\$} \mathbf{k W h}$ \\
\hline Jan-93 & 18,165 & $2,370,212$ & $7,024,500$ & $9,394,712$ & $\$ 865,503$ & $\$ 0.0921$ \\
\hline Feb-93 & 19,153 & $2,524,413$ & $7,653,000$ & $10,177,413$ & $\$ 930,286$ & $\$ 0.0914$ \\
\hline Mar-93 & 18,948 & $2,461,336$ & $6,906,539$ & $9,367,875$ & $\$ 871,021$ & $\$ 0.0930$ \\
\hline Apr-93 & 18,631 & $2,269,948$ & $7,934,929$ & $10,204,877$ & $\$ 919,757$ & $\$ 0.0901$ \\
\hline May-93 & 17,333 & $1,913,945$ & $6,676,244$ & $8,590,189$ & $\$ 796,417$ & $\$ 0.0927$ \\
\hline Jun-93 & 17,913 & $1,991,647$ & $6,964,500$ & $8,956,147$ & $\$ 828,057$ & $\$ 0.0925$ \\
\hline Jul-93 & 19,146 & $2,172,946$ & $8,314,500$ & $10,487,446$ & $\$ 1,023,432$ & $\$ 0.0976$ \\
\hline Aug-93 & 19,907 & $2,313,908$ & $7,698,000$ & $10,011,908$ & $\$ 1,000,166$ & $\$ 0.0999$ \\
\hline Sep-93 & 19,473 & $2,231,439$ & $7,915,500$ & $10,146,939$ & $\$ 1,003,755$ & $\$ 0.0989$ \\
\hline Oct-93 & 17,710 & $2,421,859$ & $7,915,500$ & $10,337,359$ & $\$ 994,926$ & $\$ 0.0962$ \\
\hline Nov-93 & 17,432 & $2,309,034$ & $6,904,500$ & $9,213,534$ & $\$ 909,394$ & $\$ 0.0987$ \\
\hline Dec-93 & 17,003 & $2,523,191$ & $7,776,000$ & $10,299,191$ & $\$ 983,021$ & $\$ 0.0954$ \\
\hline Total/Avg & 18,401 & $27,503,878$ & $89,683,712$ & $117,187,590$ & $\$ 11,125,735$ & $\$ 0.0949$ \\
\hline
\end{tabular}


Table 4. Newport Electric Corporation rate schedule at NETC.

\begin{tabular}{|c|c|c|}
\hline \multicolumn{3}{|l|}{ Demand Charge } \\
\hline On-Peak (\$/kW) & $\$ 13.26$ & \\
\hline \multicolumn{3}{|l|}{ Energy Charge* } \\
\hline On-Peak (\$/kWh) & $\$ 0.044670$ & \\
\hline Off-Peak (\$/kWh) & $\$ 0.038980$ & \\
\hline Avg. Adj. (\$/kWh)* & $\$ 0.027480$ & \\
\hline \multicolumn{3}{|l|}{ Hours/Year } \\
\hline On-Peak & 1,764 & $20.1 \%$ \\
\hline \multirow[t]{2}{*}{ Off-Peak } & $\underline{6,996}$ & $79.9 \%$ \\
\hline & 8,760 & \\
\hline \multicolumn{3}{|l|}{ Savings/Year (90\% ELF) } \\
\hline On-Peak Energy & $\$ 22,909$ & \\
\hline \multirow[t]{2}{*}{ Off-Peak Energy } & $\$ 83,692$ & \\
\hline & $\$ 106,601$ & \\
\hline Demand (200 kW) & $\$ 31,824$ & \\
\hline Total Savings; & $\$ 138,425$ & \\
\hline Average \$/kWh: & $\$ 0.0878$ & \\
\hline
\end{tabular}

Table 5 lists the first year electric savings from a $200 \mathrm{~kW}$ fuel cell based on a 90 percent electric capacity factor. It was assumed that the fuel cell outage hours during the on/off-peak periods occurred at the same percentages (Table 4).

In other words, outage hours were not weighted more heavily in either the onpeak or off-peak periods, but were proportional to the number of period hours in a year. Total first year electric savings using a 90 percent electricity capacity factor was $\$ 138,425$, which includes full demand charge savings. This works out to an average displaced electric rate of 8.78 cents $/ \mathrm{kWh}$ ( $\$ 25.72 / \mathrm{MBtu})$, which is slightly less than the 1991-1992 DEIS database average of 9.19 cents/kWh (\$26.92/MBtu).

Based on thermal utilization assumptions and an electric capacity factor of 90 percent, the potential energy savings from a $200 \mathrm{~kW}$ fuel cell were calculated. Table 5 lists the electric and thermal savings and input natural gas costs for Boiler Plant \#1. The net savings for 100 percent thermal utilization was $\$ 106,159$ in the first year, $\$ 103,036$ based on 90 percent thermal utilization and $\$ 93,656$ based on 60 percent thermal utilization. Thermal utilization is dependent on the number of hours that Boiler Plant \#7 operates in the year. 
Table 5. Economic savings of fuel cell design alternatives.

\begin{tabular}{|l|c|c|c|c|c|c|c|c|}
\hline Case & ECF & TU & $\begin{array}{c}\text { Displaced } \\
\text { kWh }\end{array}$ & $\begin{array}{c}\text { Displaced } \\
\text { Gas (MBtu) }\end{array}$ & $\begin{array}{c}\text { Electrical } \\
\text { Savings }\end{array}$ & $\begin{array}{c}\text { Thermal } \\
\text { Savings }\end{array}$ & $\begin{array}{c}\text { Nat. Gas } \\
\text { Cost }\end{array}$ & $\begin{array}{c}\text { Net } \\
\text { Savings }\end{array}$ \\
\hline A - Max. Thermal & $90 \%$ & $100 \%$ & $1,576,800$ & 7,357 & $\$ 138,425$ & $\$ 31,267$ & $\$ 63,533$ & $\$ 106,159$ \\
\hline A - $90 \%$ Thermal Utilization & $90 \%$ & $90 \%$ & $1,576,800$ & 6,622 & $\$ 138,425$ & $\$ 28,144$ & $\$ 63,533$ & $\$ 103,036$ \\
\hline A - $60 \%$ Thermal Utilization & $90 \%$ & $60 \%$ & $1,576,800$ & 4,415 & $\$ 138,425$ & $\$ 18,764$ & $\$ 63,533$ & $\$ 93,656$ \\
\hline B - Max. Thermal & $90 \%$ & $100 \%$ & $1,576,800$ & 7,357 & $\$ 122,513$ & $\$ 31,267$ & $\$ 63,533$ & $\$ 90,247$ \\
\hline B - 90\% Thermal Utilization & $90 \%$ & $90 \%$ & $1,576,800$ & 6,622 & $\$ 122,513$ & $\$ 28,144$ & $\$ 63,533$ & $\$ 87,124$ \\
\hline B - $60 \%$ Thermal Utilization & $90 \%$ & $60 \%$ & $1,576,800$ & 4,415 & $\$ 122,513$ & $\$ 18,764$ & $\$ 63,533$ & $\$ 77,744$ \\
\hline C - Max. Thermal & $90 \%$ & $100 \%$ & $1,576,800$ & 7,357 & $\$ 106,601$ & $\$ 31,267$ & $\$ 63,533$ & $\$ 74,335$ \\
\hline C- $90 \%$ Thermal Utilization & $90 \%$ & $90 \%$ & $1,576,800$ & 6,622 & $\$ 106,601$ & $\$ 28,144$ & $\$ 63,533$ & $\$ 71,212$ \\
\hline C - $60 \%$ Thermal Utilization & $90 \%$ & $60 \%$ & $1,576,800$ & 4,415 & $\$ 106,601$ & $\$ 18,764$ & $\$ 63,533$ & $\$ 61,832$ \\
\hline D - Max. Thermal & $90 \%$ & $100 \%$ & $1,576,800$ & 7,357 & $\$ 138,425$ & $\$ 31,267$ & $\$ 71,007$ & $\$ 98,685$ \\
\hline D- $90 \%$ Thermal Utilization & $90 \%$ & $90 \%$ & $1,576,800$ & 6,622 & $\$ 138,425$ & $\$ 28,144$ & $\$ 71,007$ & $\$ 95,562$ \\
\hline D - $60 \%$ Thermal Utilization & $90 \%$ & $60 \%$ & $1,576,800$ & 4,415 & $\$ 138,425$ & $\$ 18,764$ & $\$ 71,007$ & $\$ 86,182$ \\
\hline Assur
\end{tabular}

\section{Assumptions:}

Input Natural Gas Rate: $\quad \$ 4.25 / \mathrm{MBtu}$

Displaced Thermal Gas Rate: $\$ 4.25 / \mathrm{MBtu}$

Displaced Electricity Rate: NETC Contract

Fuel Cell Thermal Output: $\quad 700,000 \mathrm{Btu} / \mathrm{hr}$

Fuel Cell Electrical Efficiency: $36 \%$

Seasonal Boiler Efficiency: $\quad 75 \%$

Case A: full fuel cell demand savings

Case B: $50 \%$ of full fuel cell demand savings

Case C: zero fuel cell demand savings

Case D: Case A with "firm" input natural gas @ \$4.75/MBtu w/full fuel cell demand savings

$\mathrm{ECF}=$ Fuel cell electric capacity factor

$\mathrm{TU}=$ Thermal Utilization 
As shown by the data listed in Table 2, a thermal utilization of 60 percent would have been achieved in the years FY91 and FY92, while in FY93 it would have been over 90 percent. The data in Table 5 also show the impact of only achieving 50 percent electric demand savings, zero electric demand savings and running the fuel cell at the $\$ 4.75 / \mathrm{MBtu}$ firm gas rate. The difference between the firm and the interruptible gas rate is at most $\$ 7,474$ in the first year. (Note that a 90 percent electric capacity factor assumes that the fuel cell will only be down 36 days/year, rather than the 60 day potential for the interruptible gas rate. If the fuel cell is shut down for more than 36 days, then the $\$ 7,474$ interruptible rate advantage would be lower.)

The analysis is a general overview of the economics. For the first 5 years, ONSI will be responsible for the fuel cell maintenance. Maintenance costs are not re flected in this analysis, but could represent a significant impact on net energy savings. Since load profile data were not available, energy savings could vary depending on actual electrical and thermal utilization. 


\section{Conclusions and Recommendations}

Boiler Plant \#/ at NETC represents a good application of a $200 \mathrm{~kW}$ fuel cell. The thermal load of the plant when in operation is larger than what the fuel cell can deliver. No thermal storage is needed at the facility. Maximizing operation of Boiler Plant \#/ optimizes utilization of the fuel cell thermal output. The warehouse would need to be demolished to site the fuel cell at the proposed location. Delays in demolition would slow the installation of the fuel cell or require relocation.

Because of underground piping, it is recommended that the thermal and electrical interfaces be trellised over to the building. The thermal interface is just across from the fuel cell site. The electrical interface will need to run along the west and north sides of the building to connect with the existing transformer.

The fuel cell could also be located next to Boiler Plant \#7. The truck road would have to be redirected around the fuel cell installation. 


\section{Appendix: Fuel Cell Site Evaluation Form}

Site Name: Newport Naval Education and Training Center

Location: Newport, RI

Contacts: John Alfano

1. Electric Utility: Newport Electric Corp. Rate Schedule: Negotiated Contract Contact: Alan Salk

2. Gas Utility: Providence Gas Company Rate Schedule: To be negotiated Contact: Joe McLaughlin

3. Available Fuels: Natural Gas, Fuel Oil

Capacity Rate:

4. Hours of Use and Percent Occupied:

Weekdays Saturday

Plant runs 6-11 months/year

\begin{tabular}{|c|c|}
\hline $100 \%$ & Hrs 24 \\
\hline 100 & Hrs 24 \\
\hline 10 & Hrs 24 \\
\hline
\end{tabular}

5. Outdoor Temperature Range: Teens - $95^{\circ} \mathrm{F}$

6. Environmental Issues: Non-attainment area

7. Backup Power Need/Requirement: Caterpillar 500 kW reciprocating engine at Boiler Plant \#7

8. Utility Interconnect/Power Quality Issues:

9. On-site Personnel Capabilities: Gas Company will perform fuel cell maintenance

10. Access for Fuel Cell Installation: Truck access O.K.

11. Daily Load Profile Availability: No electric data available

12. Security: No fence required 


\section{Site Layout}

Facility Type: Central Boiler Plant

Age: 1950s

Construction: Concrete block

Square Feet: 10,000 sq ft

See Figure 1

Show:

electrical/thermal/gas/water interfaces and length of runs drainage building/fuel cell site dimensions ground obstructions 


\section{Electrical System}

Service Rating: $2400 / 480$ volt transformer (500 kVA)

Electrically Sensitive Equipment: None

Largest Motors (hp, usage):

Grid Independent Operation?: No 


\section{Steam/Hot Water System}

Description: Riley Stoker Corp (2); Nebraska Boiler Co. (1)

System Specifications: 2 - 75,000 lb/hr; 1 - 80,000 lb/hr

Fuel Type: Fuel oil, natural gas installed for Nebraska boiler

Max Fuel Rate:

Storage Capacity/Type:

Interface Pipe Size/Description:

End Use Description/Profile: Steam from the boiler is used to send out steam for heating, cooking and misc. uses.

See Figure 1 


\section{Space Cooling System}

Description: None

Air Conditioning Configuration:

Type:

Rating:

Make/Model:

Seasonality Profile: 


\section{Space Heating System}

Description: No space heating system noted in facility; hydronic systems on base

Fuel:

Rating:

Water supply Temp:

Water Return Temp:

Make/Model:

Thermal Storage (space?):

Seasonality Profile: None available 


\section{Billing Data Summary}

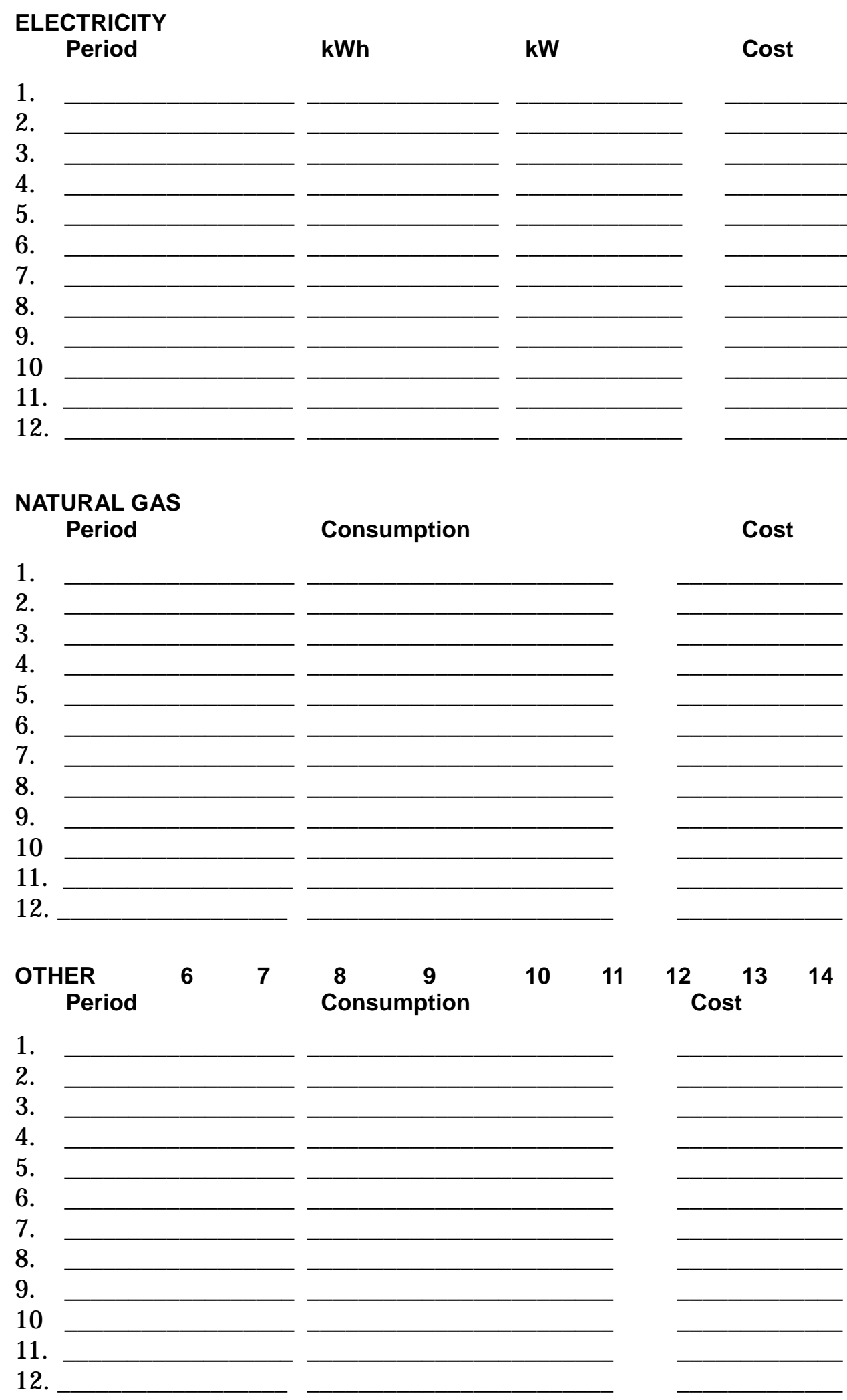




\section{CERL Distribution}

Commander, Naval Education Training Center

ATTN: Engineerng Division, Code 422 (2)

Chief of Engineers

ATTN: CEHEC-IM-LH (2)

Engineer Research and Development Center (Libraries)

ATTN: ERDC, Vicksburg, MS

ATTN: Cold Regions Research, Hanover, NH

ATTN: Topographic Engineering Center, Alexandria, VA

Defense Tech Info Center 22304

ATTN: DTIC-O

8

$12 / 00$ 


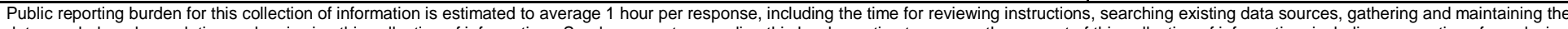

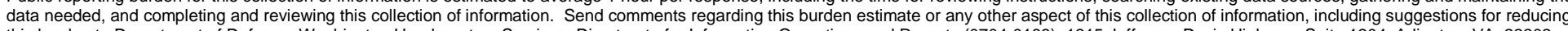

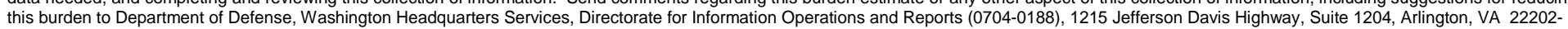

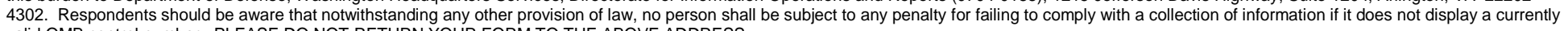
valid OMB control number. PLEASE DO NOT RETURN YOUR FORM TO THE ABOVE ADDRESS.
1. REPORT DATE (DD-MM-YYYY)
$02-2001$
2. REPORT TYPE
Final

3. DATES COVERED (From - To)

4. TITLE AND SUBTITLE

Site Evaluation for Application of Fuel Cell Technology:

Naval Education Training Center, Newport, RI

5a. CONTRACT NUMBER

88-94-D-0020

5b. GRANT NUMBER

5c. PROGRAM ELEMENT NUMBER

6. AUTHOR(S)

Michael J. Binder, Franklin H. Holcomb, and William R. Taylor

5d. PROJECT NUMBER

DACA

5e. TASK NUMBER

5f. WORK UNIT NUMBER

7. PERFORMING ORGANIZATION NAME(S) AND ADDRESS(ES)

U.S. Army Engineer Research and Development Center (ERDC)

Construction Engineering Research Laboratory (CERL)

8. PERFORMING ORGANIZATION REPORT

NUMBER

ERDC/CERL TR-01-21

PO Box 9005

Champaign, IL 61826-9005

\section{SPONSORING / MONITORING AGENCY NAME(S) AND ADDRESS(ES)}

Naval Education Training Center

Public Works Department One Simonpietri Drive

Newport, RI 02841-1711

10. SPONSOR/MONITOR'S ACRONYM(S)

Code 422

11. SPONSOR/MONITOR'S REPORT NUMBER(S)

\section{DISTRIBUTION / AVAILABILITY STATEMENT}

Approved for public release; distribution is unlimited.

13. SUPPLEMENTARY NOTES

Copies are available from the National Technical Information Service, 5285 Port Royal Road, Springfield, VA 22161.

\section{ABSTRACT}

Fuel cells are an environmentally clean, quiet, and a highly efficient method for generating electricity and heat from natural gas and other fuels. Researchers at the U.S. Army Engineer Research and Development Center (ERDC), Construction Engineering Research Laboratory (CERL) have actively participated in the development and application of advanced fuel cell technology since fiscal year 1993 (FY93). CERL selected and evaluated application sites, supervised the design and installation of fuel cells, actively monitored the operation and maintenance of fuel cells, and compiled "lessons learned" for feedback to manufacturers for 29 of 30 commercially available fuel cell power plants and their thermal interfaces installed at Department of Defense (DoD) locations.

This report presents an overview of the information collected at the Naval Education Training Center, Newport, RI, along with a conceptual fuel cell installation layout and description of potential benefits the technology can provide at that location. Similar summaries of the site evaluation surveys for the remaining 28 sites where CERL has managed and continues to monitor fuel cell installation and operation are available in the companion volumes to this report.

\section{SUBJECT TERMS}

fuel cells

energy conservation

energy technology alternatives

16. SECURITY CLASSIFICATION OF:

Naval Education Training Center, Newport, RI

\section{a. REPORT}

Unclassified

\section{b. ABSTRACT \\ Unclassified}

\begin{tabular}{|c|c|}
\hline $\begin{array}{l}\text { 17. LIMITATION } \\
\text { OF ABSTRACT }\end{array}$ & $\begin{array}{l}\text { 18. NUMBER } \\
\text { OF PAGES }\end{array}$ \\
\hline SAR & 28 \\
\hline
\end{tabular}

19a. NAME OF RESPONSIBLE PERSON Michael J. Binder

19b. TELEPHONE NUMBER (include area code)

(217) 373-1274 